\title{
Keragaman Mikroflora, Mikrofauna, Kandungan C-organik, dan Total N Tanah Sawah Akibat Aplikasi Azolla dan Pupuk Hayati
}

\author{
Mieke Rochimi Setiawati, Pujawati Suryatmana dan Tualar Simarmata \\ Departemen Ilmu Tanah dan Sumberdaya Lahan, Fakultas Pertanian Universitas Padjadjaran \\ Jl. Raya Bandung Sumedang Km 21 Jatinangor \\ Korespondensi: m.setiawati@unpad.ac.id
}

\begin{abstract}
This study was conducted to determine the effect of Azolla pinnata and biofertilizers (Azotobacter and Phosphate Solubilizing Bacteria) on the total microflora, microfauna, organic C, $\mathrm{N}$-total soil, and $C / N$ ratio of soil in lowland rice. The study was carried out in the SPLPP experimental field (Agricultural Research and Development Research Studio) of the Faculty of Agriculture, Padjadjaran University, Jelekong Village, Ciparay, Bandung Regency, West Java, with an altitude of 628 meters above the sea level. The experimental design used was factorial randomized block design consisted of two factors and repeated four times. The first factor was the provision of Azolla with two levels: without Azolla and 3 tons ha-1 of Azolla pinnata. The second factor was the provision of biofertilizer with three levels, without biofertilizer, $5 \mathrm{~L} \mathrm{ha}^{-1}$ biofertilizer, and $10 \mathrm{~L} \mathrm{ha}^{-1}$ biofertilizer. The results showed that there was an interaction between A. pinnata with biofertilizer on the increase in the total bacterial population. Total fungus, microfauna (nematodes), and soils $N$-total content did not increase with the addition of Azolla or biofertilizers. Independently A. pinnata increased soil C-organic matter while biofertilizer $10 \mathrm{~L} \mathrm{ha}^{-1}$ increased the total population of actinomycetes.
\end{abstract}

Keywords: Azolla, Azotobacter, Phosphate Solubilizing Bacteria, Rice, Biofertilizer

\section{PENDAHULUAN}

Pertanian dengan masukan rendah (low input agriculture) merupakan suatu keharusan di masa kini dan masa akan datang dalam mewujudkan pertanian berkelanjutan, sehingga petani dapat memperoleh keuntungan ekonomis dari usahatani tanpa mencemari lingkungan. Saraswati et. al., (2004) menyatakan kaidah hayati yang proporsional perlu diterapkan di dalam memenuhi kebutuhan nutrisi tanaman. Penghasilan petani akan meningkat dengan penggunaan pupuk, tenaga kerja, dan produksi padi yang efisien berdasarkan respon yang positif dari peningkatan hasil yang diperoleh.

Penggunaan pupuk anorganik dengan dosis yang tinggi dalam kurun waktu yang panjang dapat menyebabkan penurunan kesuburan tanah. Dinapriatna dan Simarmata (2011), menjelaskan bahwa ketimpangan hara atau kekurangan hara dapat terjadi pada pemupukan dosis tinggi dengan waktu yang lama yang berakibat pada semakin menurunnya kandungan bahan organik tanah. Penurunan tingkat kesuburan lahan juga terjadi karena adanya eksploitasi lapisan olah tanah secara intensif yang telah berlangsung bertahun-tahun. Apabila teknik budidaya itu dilanjutkan terus, maka akan terjadi pemiskinan bahan organik tanah bahkan degradasi atau kerusakan tanah. Perbaikan sifat-sifat fisika, kimia, dan biologi tanah dapat dilakukan melalui penggunaan bahan organik. Menurut Priadi et. al. (2007) salah satu aplikasi pupuk organik tanpa mencemari lingkungan adalah penggunaan pupuk hijau tanaman paku air atau azolla.

Pemupukan dengan menggunakan azolla merupakan suatu alternatif untuk tindakan perbaikan lingkungan tumbuh tanaman padi tanpa mencemari lingkungan. Dengan pemberian Azolla kebutuhan hara tanaman padi terutama nitrogen sebagian akan terpenuhi. Kandungan nitrogen azolla dapat mencapai 5 persen dari berat keringnya. Penambahan azolla sebagai bahan organik ke dalam tanah sawah dapat memberi sumber energi bagi organisme di dalam tanah sehingga dapat berkembang dengan optimal. Hasil dekomposisi azolla di dalam tanah sawah akan meningkatkan $\mathrm{C}$ organik tanah dari hasil penguraian biomassa azolla menjadi sumber karbon 
dan nutrisi bagi mikrofauna tanah atau mikroflora yang ditambahkan sebagai pupuk hayati.

Peranan azolla di dalam tanah khususnya mikroflora (bakteri, jamur dan aktinomiset) yang bermanfaat di dalam tanah dapat membantu menyediakan sumber karbon dan unsur hara. Mikrofauna tanah (termasuk kelompok protozoa dan nematoda) yang berperan dalam mineralisasi bahan organik akan meningkat populasinya karena adanya asupan bahan organik dari Azolla. Tim Sintesis Kebijakan (2008) menjelaskan, fauna tanah memegang peranan penting dalam siklus hara di dalam tanah, sehingga dalam jangka panjang sangat mempengaruhi keberlanjutan produktivitas lahan. Mikrofauna memanfaatkan bahan organik yang halus, yang selanjutnya berubah menjadi koloid-koloid organik sehingga menyediakan nutrisi bagi organisme lain di dalam tanah.

Azolla merupakan tanaman paku air yang bersimbiosis dengan Anabaena azollae dan berfungsi sebagai penambat $\mathrm{N}_{2}$ udara. Anabaena azollae termasuk ke dalam Cyanobacteria filamentous yang tumbuh di dalam rongga udara daun azolla. Azolla memanfaatkan energi yang berasal dari hasil fotosintesis untuk mengikat $\mathrm{N}_{2}$ di udara. Menurut Sutanto (2002), kemampuan azolla mengikat $\mathrm{N}_{2}$ udara berkisar antara 400-500 kg $\mathrm{N} /$ ha/tahun. Kandungan nitrogen yang berlebih dalam tubuh azolla akan dilepaskan ke dalam media atau lingkungan tumbuhnya. Di dalam jaringan tanaman azolla kandungan nitrogen total berkisar antara $4 \%$ hingga $5 \%$ berat kering (Singh dan Subudhi, 1978). Azolla segar dapat dibenamkan ke dalam tanah sehingga nitrogen yang terkandung dalam biomassa azolla dimineralisasi dan dilepaskan ke sekitar akar tanaman padi (Adhikary, 2014). Oleh karena itu, azolla sangat berpotensi sebagai sumber nitrogen alami (Maftuchah, 1994).

Pupuk hayati yang di dalamnya mengandung Azotobacter sp. dan Bakteri Pelarut Fosfat berperan dalam menaikkan kadar $\mathrm{N}$ dan $\mathrm{P}$ tanah, selain itu dapat memacu pertumbuhan tanaman melalui produksi metabolit hormon tumbuh yang bermanfaat untuk perpanjangan perakaran tanaman padi. Pupuk hayati juga dapat berfungsi meningkatkan populasi dan aktivitas organisme yang bermanfaat di dalam tanah. Sangat tepat apabila pelaku pertanian menggunakan pupuk hayati sebagai pensubstitusi pupuk utama di dalam budidaya pertanian. Berbagai aktivitas mikroorganisme tanah, mikroflora dan fauna saling mendukung keberlangsungan proses siklus hara, membentuk susunan biota tanah yang mengatur proses fisika, kimia, dan hayati tanah.

Keterkaitan antara azolla dan pupuk hayati memberikan dampak positif bagi kesuburan tanah dan pertumbuhan tanaman padi karena unsur hara dapat tersedia optimal bagi tanaman. Aktivitas organisme tanah (mikroflora dan fauna tanah) dapat berjalan dengan baik dan populasinya akan bertambah karena ketersediaan bahan organik sebagai sumber makanan atau aktivitasnya tersedia di dalam tanah. Penelitian ini dilakukan untuk mengkaji pengaruh pemberian azolla dan pupuk hayati terhadap kelimpahan mikroflora dan mikrofauna tanah serta kandungan $\mathrm{C}$ organik dan $\mathrm{N}$ total tanah yang bermanfaat dalam meningkatkan kesuburan tanah sawah.

\section{METODOLOGI}

Tanah yang digunakan dalam penelitian ini adalah Entisol dengan sub group Typic Hydraquents. Hasil analisis tanah awal menunjukkan tekstur tanah liat dengan komposisi debu 6\%, pasir 40\%, dan liat 54\%, pH agak masam (6,1), C/N (12) dan KTK sedang $\left(21,9 \mathrm{cmol} \mathrm{kg}^{-1}\right)$, C-Organik $(1,25 \%)$ rendah, N-Total $(0,14 \%)$ rendah, K-Potensial $(0,1 \mathrm{mg} / 100 \mathrm{~g})$ dan P-Potensial rendah $(20,4$ $\mathrm{mg} / 100 \mathrm{~g})$, kejenuhan basa rendah $(31,5 \%)$. Kandungan kation-kation yang dapat ditukar seperti Na rendah $\left(0,3 \mathrm{cmol} \mathrm{kg}^{-1}\right)$, Ca tinggi $(2,6$ cmol kg-1), K sedang $\left(0,2 \mathrm{cmol} \mathrm{kg}^{-1}\right), \mathrm{Mg}$ rendah $\left(4,5 \mathrm{cmol} \mathrm{kg}^{-1}\right)$ dan Al rendah $\left(0,3 \mathrm{cmol} \mathrm{kg}^{-1}\right)$.

Metode eksperimen digunakan pada penelitian ini dengan Rancangan Acak Kelompok (RAK) pola faktorial.

Faktor perlakuan pertama yaitu pemberian azolla (A) dengan dua taraf yaitu: 
$\mathrm{a}_{0}=$ tanpa aplikasi Azolla

$\mathrm{a}_{1}=$ aplikasi Azolla dosis 3 ton ha-1 ${ }^{-1}, 6$ $\mathrm{Kg} /$ plot)

Faktor perlakuan kedua yaitu pupuk hayati $(\mathrm{H})$ yang terdiri dari tiga taraf yaitu:

$\mathrm{h}_{0}=$ tidak diberi pupuk hayati

$\mathrm{h}_{1}=$ diberi pupuk hayati dengan dosis $5 \mathrm{~L}$ ha $^{-1}$ (6 mL/plot)

$\mathrm{h}_{2}=$ diberi pupuk hayati dengan dosis $10 \mathrm{~L}$ ha $^{-1}(12 \mathrm{~mL} /$ plot $)$

Percobaan diulang 4 kali. Untuk mengetahui pengaruh perlakuan digunakan uji Fisher pada taraf nyata $5 \%$. Apabila terdapat perbedaan yang nyata, pengujian dilanjutkan dengan uji jarak duncan pada taraf nyata $5 \%$. Penetapan populasi mikroflora (bakteri, jamur, dan aktinomiset) dilakukan dengan metode total plate count (TPC), sedangkan populasi mesofauna tanah ditetapkan dengan metode corong Bearmann.

Persemaian benih padi dilakukan di petak persemaian dengan luas persemaian empat persen dari luas areal yang ditanami. Benih padi yang telah disemai selama 14 hari, langsung ditanam di lahan sawah yang telah diolah. Pengolahan tanah pada lahan dilakukan dua kali. Pengolahan tanah yang pertama, tanah dibajak dengan tujuan untuk pembalikan tanah, setelah itu dibiarkan selama seminggu. Pengolahan tanah kedua, tanah digaru dihaluskan kemudian dibuat petak-petak percobaan yang berukuran $3 \times 4$ meter dengan jarak antar petak 0,5 meter yang dijadikan galengan beserta saluran pemasukan dan pembuangan air.

Pemeliharaan tanaman padi sawah yang dilakukan yaitu pemupukan, pengaturan air, dan pemberantasan hama. Pemberian pupuk dasar urea diberikan dua kali dengan dosis 200 $\mathrm{kg} \mathrm{ha}^{-1}, 50 \%$ dosis diberikan pada umur padi 2 MST, 50\% dosis diberikan pada umur padi 6 MST. Pupuk SP-36 dosis $100 \mathrm{~kg} \mathrm{ha}^{-1}$, dan $\mathrm{KCl}$ dosis $100 \mathrm{~kg} \mathrm{ha}^{-1}$ diberikan seluruhnya pada saat tanam. Pemupukan N, P dan K dilakukan secara sebar langsung. Pemberian air pada tanaman padi di petakan diatur sesuai dengan budidaya tanaman padi sawah. Pemberian air dilakukan dengan cara menggenangi sawah de- ngan ketinggian $5 \mathrm{~cm}$ pada umur 0 sampai 10 hari. Pada umur 10 sampai 100 hari pemberian air setinggi $0 \mathrm{~cm}$ (macak-macak) sampai $5 \mathrm{~cm}$. Pada umur 110 hari pemberian air pada sawah di hentikan sampai tanah kering.

Azolla diberikan setengah dosis $(1,5$ ton ha $^{-1}$ ) pada saat tanam padi dengan cara dibenamkan pada tanah dan setengah dosis lainnya ditebarkan pada lahan sawah dan dibiarkan tumbuh bersama tanaman padi. Pada saat penyiangan gulma (4 MST) azolla yang sebelumnya dibiarkan tumbuh turut dibenamkan bersama gulma, sisanya dibiarkan tumbuh dan dilakukan hal yang sama sampai kanopi tanaman padi saling menutupi dan azolla tidak tumbuh. Pupuk hayati diberikan pada saat tanam dan setiap 1 minggu sekali sampai 8 MST dengan dosis sesuai perlakuan disemprotkan ke tanah dalam kondisi tanah macakmacak.

\section{HASIL DAN PEMBAHASAN}

\subsection{Mikroflora Tanah}

Populasi mikroflora yang diamati pada percobaan ini adalah golongan mikroorganisme yang dominan terdapat di dalam tanah yaitu bakteri, jamur, dan aktinomiset. Populasi bakteri, aktinomisetes, dan jamur di dalam 1 gram tanah yang subur berturut turut mengandung $10^{8}-10^{9} \mathrm{CFU}^{-1}, 10^{7}-10^{8} \mathrm{CFU}^{-1}$, dan 105-106 CFU-1 (Coleman et. al., 2018). Ketiga jenis mikroflora tersebut berperan penting di alam antara lain dalam transformasi unsur hara C, N, P dan unsur lainnya (Roper and Ophel-Keller, 1997).

Analisis populasi mikroflora tanah dilakukan pada sampel tanah rhizosfir yang diambil saat pengambilan sampel tanah pada fase vegetatif maksimum ( 8 MST). Terjadi interaksi antara pemberian azolla dengan pupuk hayati terhadap jumlah populasi bakteri (Tabel 1). Efek interaksi tidak terdapat antara pemberian azolla dengan pupuk hayati terhadap populasi aktinomiset dan jamur.

Populasi bakteri meningkat dengan adanya pemberian pupuk hayati, peningkatan populasi bakteri terlihat nyata pada tanah sawah yang ditambahkan azolla pada pupuk hayati dengan 
dosis $10 \mathrm{~L} \mathrm{ha}^{-1}$. Sedangkan bila dosis pupuk hayati yang ditambahkan $5 \mathrm{~L} \mathrm{ha}^{-1}$ peningkatan populasi bakteri tidak nyata atau sama dengan kontrol (tanpa diberi pupuk hayati). Pemberian azolla meningkatkan populasi bakteri pada tanaman yang diberi pupuk hayati $10 \mathrm{~L}$ ha $^{-1}$.

Tabel 1 Populasi Bakteri yang diberi azolla dan pupuk hayati

\begin{tabular}{|c|c|c|c|}
\hline \multirow[b]{2}{*}{ Perlakuan } & \multicolumn{3}{|c|}{$\begin{array}{l}\text { Populasi bakteri } \\
\qquad\left(10^{9} \mathrm{CFU} \mathrm{g}^{-1}\right)\end{array}$} \\
\hline & $\begin{array}{c}\mathrm{h}_{0} \\
\text { (tanpa } \\
\text { pupuk } \\
\text { hayati) }\end{array}$ & $\begin{array}{c}\mathrm{h}_{1} \\
\left(5 \mathrm{~L} \mathrm{ha}^{-1}\right)\end{array}$ & $\begin{array}{c}\mathrm{h}_{2} \\
\left(10 \mathrm{~L}^{-h^{-1}}\right)\end{array}$ \\
\hline $\mathrm{a}_{0}$ & $1,91 \mathrm{a}$ & $5,78 \mathrm{a}$ & $4,31 \mathrm{a}$ \\
\hline (Tanpa azolla) & A & B & $\mathrm{AB}$ \\
\hline $\mathrm{a}_{1}$ & $3,43 \mathrm{~b}$ & $4,61 \mathrm{a}$ & $12,73 \mathrm{~b}$ \\
\hline (Azolla 3 t ha $^{-1}$ ) & A & $\mathrm{A}$ & B \\
\hline $\begin{array}{r}\text { Keterangan }: \text { Huru } \\
\text { huruf } \\
\text { Angk } \\
\text { diiku } \\
\text { tidak } \\
\text { berga }\end{array}$ & $\begin{array}{l}\text { besar dil } \\
\text { ecil diba } \\
\text { rata-rat } \\
\text { huruf y } \\
\text { erbeda } \\
\text { da Dunce }\end{array}$ & $\begin{array}{l}\text { ca arah ho } \\
\text { arah vertil } \\
\text { pada tiap } \\
\text { ng sama n } \\
\text { yata menu }\end{array}$ & $\begin{array}{l}\text { rizontal dan } \\
\text { zal. } \\
\text { kolom yang } \\
\text { nenunjukkan } \\
\text { cut uji jarak } \\
5 \% \text {. }\end{array}$ \\
\hline
\end{tabular}

Pada tanah yang tidak diberi pupuk hayati, pemberian azolla meningkatkan populasi bakteri yang berarti dapat memacu populasi bakteri indigenus. Pupuk hayati $5 \mathrm{~L} \mathrm{ha}^{-1}$ belum dapat menaikkan populasi bakteri tanah sawah walaupun diberi azolla 3 ton ha-1. Hal ini disebabkan pupuk hayati sebesar $5 \mathrm{~L} \mathrm{ha}^{-1}$ yang ditambahkan belum dapat memicu pertumbuhan bakteri secara nyata. Sebagian besar bakteri heterotrof di dalam tanah memerlukan bahan organik untuk sumber energinya. Dosis pupuk hayati yang besar (10 L ha-1) menyebabkan semua bahan organik yang berasal dari azolla dapat dimanfaatkan untuk pertumbuhannya sehingga populasinya meningkat dengan cepat.

Lingkungan bagi organisme tanah akan berubah ketika azolla diberikan ke dalam tanah yang berfungsi sebagai nutrisi sebagai sumber energi bagi organisme tanah. Aplikasi $A$. pinnata dan penambahan pupuk hayati dengan dosis yang lebih besar akan meningkatkan pertumbuhan bakteri akibat mikroorganisme yang ditambahkan ke dalam tanah membantu dekomposisi $A$. pinnata dengan baik sehingga karbon yang dihasilkan dapat segera menjadi sumber nutrisi bakteri tanah. Dengan kata lain perlakuan azolla 3 ton ha $^{-1}$ yang diberi pupuk hayati $10 \mathrm{~L} \mathrm{ha}^{-1}$ merupakan kombinasi perlakuan yang paling baik terhadap total populasi bakteri.

Penambahan populasi bakteri di tanah sawah akibat pemberian pupuk hayati berkaitan erat dengan adanya Azotobacter dan BPF dari pupuk hayati yang sangat penting dalam mensuplai nutrisi di dalam tanah. Menurut Sivasakthi et. al. (2017) Azotobacter sp. adalah bakteri pemfiksasi $\mathrm{N}_{2}$ hidup bebas, dapat tumbuh di zona rizosfer gandum, jagung, padi, dll. dan dapat menambat $\mathrm{N}$ sebesar 10-20 kg.ha-1 tiap musim tanam. Azotobacter mensintesis dan mengeluarkan sejumlah besar senyawa biologis secara aktif seperti vitamin $B$, asam nikotinat, asam pentothenic, biotin, heteroauxins, dan giberelin dll, yang mening-katkan pertumbuhan akar tanaman. Karakteristik penting lainnya Azotobacter sp. asosiasi dengan kehadiran eksudat akar, yang membantu dalam modifikasi serapan hara oleh tanaman. Awais et. al. (2017) menyatakan BPF yang diisolasi dari akar tanaman padi memiliki kemampuan untuk melarutkan fosfor yang tidak larut agar tersedia bagi akar tanaman untuk diserap. Disamping itu, bakteri tersebut mempunyai kemampuan memproduksi asam indol asetat (IAA), aktivitas antagonis terhadap patogen jamur dan resistensi terhadap antibiotik intrinsik.

Pemberian A. pinnata tidak meningkatkan populasi Aktinomiset dibandingkan tanpa pemberian azolla (Tabel 2). Walaupun populasi Aktinomiset meningkat sebesar 25,3\% akibat pemberian $A$. pinnata 3 ton ha- ${ }^{-1}$ dibandingkan dengan tanpa pemberian $A$. pinnata. Kanti (2005) menyatakan jumlah aktinomiset meningkat dengan adanya bahan organik yang mengalami dekomposisi. Hal tersebut diduga bahan organik yang berasal dari azolla telah termineralisasi pada 8 MST sehingga sebagian besar nutrisi di dalam tanah sudah menurun yang berakibat terhadap peningkatan populasi aktinomiset menjadi lambat. 
Pemberian pupuk hayati $10 \mathrm{~L} \mathrm{ha}^{-1}$ dapat menaikkan populasi aktinomisetes dibandingkan dengan pemberian pupuk hayati $5 \mathrm{~L} \mathrm{ha}^{-1}$. Hal ini disebabkan penambahan pupuk hayati dapat meningkatkan ketersediaan $\mathrm{N}$ dan $\mathrm{P}$ di dalam tanah akibat aktivitas bakteri penambat N Azotobacter sp. dan BPF yang berasal dari pupuk hayati. Dengan meningkatnya kandungan $\mathrm{N}$ dan $\mathrm{P}$ di dalam tanah maka aktinomiset mendapatkan nutrisi anorganik untuk pertumbuhannya.

Tabel 2 Populasi aktinomiset dan jamur yang diberi azolla dan pupuk hayati

\begin{tabular}{|c|c|c|}
\hline \multirow{2}{*}{ Perlakuan } & \multicolumn{2}{|c|}{$\begin{array}{c}\text { Populasi Mikroflora } \\
\text { Tanah (CFU/g) }\end{array}$} \\
\hline & $\begin{array}{c}\text { Aktinomiset } \\
\left(10^{6}\right)\end{array}$ & $\begin{array}{l}\text { Jamur } \\
\left(10^{4}\right)\end{array}$ \\
\hline \multicolumn{3}{|l|}{ Azolla (A) } \\
\hline ao (tidak diberi Azolla) & $3,85 \mathrm{a}$ & $2,71 \mathrm{a}$ \\
\hline $\mathrm{a}_{1}\left(\right.$ diberi Azolla 3 t.ha $\left.^{-1}\right)$ & $5,15 \mathrm{a}$ & $2,53 \mathrm{a}$ \\
\hline \multicolumn{3}{|l|}{ Pupuk Hayati (H) } \\
\hline ho (tanpa pupuk hayati) & $4,36 \mathrm{ab}$ & $2,45 \mathrm{a}$ \\
\hline $\mathrm{h}_{1}\left(5 \mathrm{~L} \cdot \mathrm{ha}^{-1}\right)$ & $3,46 \mathrm{a}$ & $3,08 \mathrm{a}$ \\
\hline $\mathrm{h}_{2}\left(10\right.$ L.ha $\left.^{-1}\right)$ & $5,68 \mathrm{~b}$ & $2,35 \mathrm{a}$ \\
\hline
\end{tabular}

Menurut (Saraswati, 2008) penggenangan tanah akan menurunkan secara perlahan konsentrasi oksigen yang diikuti oleh proses reduksi berbagai komponen mineral. Berkurangnya oksigen menurunkan populasi mikroba aerob obligat dan meningkatkan populasi mikroba anaerob. Proses pengge-nangan pada lahan sawah akan mengakibatkan aktivitas mikroba akan tertekan dan mengalami penurunan jumlah populasi aerob.

Populasi jamur tidak dipengaruhi oleh penambahan pupuk hayati maupun pemberian azolla (Tabel 2). Menurut Srikandi (1989) jamur umumnya tumbuh lebih lambat dibandingkan dengan bakteri. Bila lingkungan tumbuh cocok bagi mikroba, umumnya jamur lebih lambat dalam bersaing dibandingkan dengan bakteri. Jamur mampu berkembang pada $\mathrm{pH}$ rendah. Penggenangan akan memperhambat pertumbuhan jamur, karena pada tanah yang tergenang $\mathrm{pH}$ meningkat mendekati netral dan pada keadaan banyak air spora sulit berkembang sehingga populasi jamur tidak meningkat.

Karakter mikroflora dalam tanah dapat berubah akibat penggenangan. Bakteri merupakan mikroflora yang dominan pada berbagai tanah di Asia yang digenangi, sebaliknya aktinomiset dan jamur lebih dominan pada tanah tegalan (Yoshida, 1978). Tanah yang tergenang dapat menghambat perkembangan jamur dan aktinomiset, sedangkan tanah tegalan yang kering atau lembab dapat menjaga populasi jamur dan aktinomiset dalam populasi yang cukup banyak karena terbentuk spora (Kanti, 2005).

\subsection{Mikrofauna Tanah}

Rantai makanan yang terbentuk pada tanah tergenang mempunyai ciri yang khas akibat adanya interaksi berbagai biota tanah (Kuwabara, 1999). Struktur komunitas organisme di dalam lingkungan tanah sawah yang tersusun atas larva serangga, moluska, protozoa, nematoda, alga, dll dipengaruhi oleh aktivitas organisme tersebut (Adrian dan Schneider-Olt, 1999). Faktor lingkungan seperti pemberian pupuk organik dan anorganik, penggenangan, pestisida, pengaturan air, varietas tanaman, dan lainnya juga berpengaruh terhadap populasi biota tanah (Simpson et. al., 1994).

Fauna tanah diklasifikasikan ke dalam tiga kelompok berdasarkan ukuran tubuh, mikrofauna (lebar tubuh $<0,2 \mathrm{~mm}$ ), mesofauna $(0,2$ $2 \mathrm{~mm})$, dan makrofauna $(2,0 \mathrm{~mm}-20,0 \mathrm{~mm})$ (Lavelle dan Spain, 2001). Mikrofauna yang banyak terdapat di dalam tanah yang tergenang seperti sawah yaitu protozoa dan nematoda. Protozoa tidak ditemukan pada penelitian ini, sedangkan nematoda terlihat berlimpah. Protozoa tidak ditemukan diduga karena pengaruh penggunaan pupuk kimia dan pestisida. Pada penelitian ini, seluruh fauna yang dapat dijaring dan dihitung populasinya adalah fauna dari golongan nematoda.

Nematoda ada yang bersifat patogen pada tanaman dan ada pula yang non patogen. Nematoda non patogen berperan dalam 
mendegradasi bahan organik menjadi senyawa anorganik yang bermanfaat untuk tanaman maupun organisme sekitarnya. Hardjowigeno (2007) menyatakan bahwa berdasarkan jenis makanannya nematoda dibedakan menjadi omnivorous (memakan sisa-sisa bahan organik, merupakan nematoda yang paling umum ditemukan di tanah), predaceous (memakan hewan-hewan tanah), dan parasitik (merusak akar tanaman). Pada penelitian ini, sebagian besar nematoda yang dihitung dengan metode corong Bearmann merupakan nematoda yang non patogen yang ditunjukkan oleh ujung mulutnya yang tumpul. Menurut Mirsam dan Kurniawati (2018) nematoda perusak akar tanaman mempunyai ciri ujung mulutnya runcing dengan bagian rongga mulut dilengkapi dengan stilet.

Penambahan bahan organik ke dalam tanah dapat meningkatkan populasi nematoda, akan tetapi penambahan azolla sebesar 3 tha $^{-1}$ tidak meningkatkan populasi nematoda (Tabel 3). Hal tersebut dapat terjadi karena azolla dalam waktu 10-15 hari sudah terdekomposisi sempurna sehingga pada saat pengamatan populasi nematoda pada 8 MST biomassa azolla sudah menurun begitu pula dengan populasi nematoda.

Tabel 3 Populasi mikrofauna (nematoda) tanah yang diberi azolla dan pupuk hayati

\begin{tabular}{cc}
\hline \multirow{2}{*}{ Perlakuan } & $\begin{array}{c}\text { Populasi } \\
\text { Nematoda }\end{array}$ \\
\cline { 2 - 2 } & (individu $/ \mathrm{m}^{3}$ ) \\
\hline
\end{tabular}

Azolla pinnata (a)

$\mathrm{a}_{0}$ (tanpa A. pinnata)

$2.925,93$ a

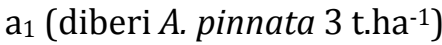

$2.679,01$ a

Pupuk Hayati (h)

$\mathrm{h}_{0}$ (tanpa pupuk hayati)

$3.703,70$ a

$\mathrm{h}_{1}\left(5{\mathrm{~L} . h a^{-1}}^{-1}\right)$

$2.981,48$ a

$\mathrm{h}_{2}\left(10\right.$ L.ha $\left.^{-1}\right)$

$1.722,22 \mathrm{a}$

Keterangan : Angka rata-rata pada tiap kolom yang diikuti huruf yang sama menunjukkan tidak berbeda nyata menurut uji jarak berganda Duncan pada taraf 5\%

Selain bahan organik sebagai nutrisi untuk nematoda, struktur tanah berpengaruh terhadap perkembangan nematoda. Ukuran pori-pori tanah yang lebih besar dari ukuran nematoda menyebabkan nematoda mampu bergerak dan beraktivitas di dalam tanah. Pada umumnya tanah berpasir merupakan lingkungan yang terbaik bagi nematoda dan tanah yang mempunyai kandungan lempung tinggi atau tanah dengan jumlah pori-pori yang banyak akan mengambat gerakan nematoda (Srikandi, 2010).

Pemberian pupuk hayati juga tidak memberikan pengaruh yang nyata terhadap jumlah populasi nematoda. Hal ini disebabkan kesamaan makanan nematoda dengan bakteri heterotrof yang berasal dari pupuk hayati (Azotobacter sp. dan BPF). Pemberian pupuk hayati mengakibatkan terjadi kompetisi antara mikroba dari pupuk hayati dengan nematoda dalam mendapatkan makanan berupa bahan organik. Menurut Rifai et. al. (2020), pada umumnya bakteri antagonis dalam aktifitas organisme yang satu dengan organisme yang lainnya akan saling bersaing dalam memperebutkan tempat, udara, air, bahan makanan (nutrient). Jika bakteri tersebut tidak saling bersaing akan tetapi bakteri tersebut berinteraksi dan bersinergi, serta kebutuhan nutrisi tidak sama dan berperilaku kooperatif antar bakteri dalam habitatnya maka dapat dikatakan sinergisme.

\subsection{Kadar C-organik, N-total, dan C/N Rasio Tanah Sawah}

Pemberian Azolla dengan dosis pupuk hayati tidak menunjukkan interaksi terhadap C-Organik, $\mathrm{N}$-total dan $\mathrm{C} / \mathrm{N}$ rasio tanah. Namun terdapat pengaruh mandiri pemberian Azolla pinnata terhadap C organik tanah. Kadar C organik tanah sawah awal sebelum perlakuan termasuk kriteria rendah (1,25\%). Dengan pengolahan tanah sawah, tunggul padi sisa tanaman padi pada panen musim tanam sebelumnya menambah kandungan $\mathrm{C}$ organik tanah menjadi $2,43 \%$. Penambahan azolla 3 ton ha $^{-1}$ terlihat menaikkan kandungan $\mathrm{C}$ organik tanah dan berbeda dengan tanpa pemberian azolla (Tabel 4). Sejalan dengan pernyataan Setyorini (2005), penambahan bahan organik ke dalam tanah akan meningkatkan kadar $\mathrm{C}$ organik tanah. Bahan organik 
berfungsi sebagai amelioran yang dapat memperbaiki jumlah dan aktivitas mikroba tanah serta sumber hara di dalam tanah sehingga dapat meningkatkan kualitas tanah.

Tabel 4 Kadar C-organik, N-total, dan C/N rasio tanah yang diberi azolla dan pupuk hayati

\begin{tabular}{|c|c|c|c|}
\hline \multirow{2}{*}{ Perlakuan } & C-organik & $\mathrm{N}$-total & \multirow{2}{*}{$\mathrm{C} / \mathrm{N}$} \\
\hline & \multicolumn{2}{|c|}{--------------------- \% ------------------- } & \\
\hline \multicolumn{4}{|l|}{ Azolla pinnata (a) } \\
\hline $\mathrm{a}_{0}(\tan p a$ A. pinnata) & $2,43 \mathrm{a}$ & $0,28 \mathrm{a}$ & $9,17 \mathrm{a}$ \\
\hline $\mathrm{a}_{1}\left(\right.$ diberi $A$. pinnata 3 t.ha $^{-1}$ ) & $2,76 \mathrm{~b}$ & $0,37 \mathrm{a}$ & $8,16 \mathrm{a}$ \\
\hline \multicolumn{4}{|l|}{ Pupuk Hayati (h) } \\
\hline $\mathrm{h}_{0}$ (tanpa pupuk hayati) & $2,68 \mathrm{a}$ & $0,31 \mathrm{a}$ & $9,79 \mathrm{a}$ \\
\hline $\mathrm{h}_{1}\left(5 \mathrm{~L} \cdot \mathrm{ha}^{-1}\right)$ & $2,47 \mathrm{a}$ & $0,30 \mathrm{a}$ & $8,32 \mathrm{a}$ \\
\hline $\mathrm{h}_{2}\left(10\right.$ L.ha $\left.^{-1}\right)$ & $2,63 \mathrm{a}$ & $0,36 \mathrm{a}$ & $7,88 \mathrm{a}$ \\
\hline
\end{tabular}

Keterangan : Angka rata-rata pada tiap kolom yang diikuti huruf yang sama menunjukkan tidak berbeda nyata menurut uji jarak berganda Duncan pada taraf $5 \%$.

Peran bahan organik akan akan jelas terlihat pada tanah dengan kadar C-organik tanah rendah $(<2 \%)$. Pada tanah sawah yang terus menerus diolah secara intensif biasanya mempunyai kadar C-organik yang rendah. Berdasarkan hasil penelitian Karama dkk. (1990) di 30 tempat lahan sawah di Indonesia yang disam-pling dengan acak menunjukkan bahwa $68 \%$ diantaranya mengandung Corganik tanah $<1,5 \%$. Sedangkan Pramono dkk. (2001) menganalisis tanah di kecamatan yang sama dengan jenis tanah yang sama mendapatkan rata-rata kandungan $\mathrm{C}$ organik tanah $<1 \%$. Pemberian pupuk hayati tidak meningkatkan C-organik tanah, namun pengaruh mandiri pupuk hayati cenderung menurunkan C-organik tanah. Hal tersebut diduga disebabkan bahan organik yang terkandung di dalam tanah digunakan sebagai sumber makanan bagi mikroorganisme heterotrof yang berasal dari pupuk hayati dan dari dalam tanah sehingga C-organik di dalam tanah berkurang keberadaannya.

Pemberian azolla dan pupuk hayati tidak memberikan pengaruh terhadap $\mathrm{N}$-total dan $\mathrm{C} / \mathrm{N}$ rasio. Namun bila dilihat pengaruh penambahan Azolla 3 ton ha-1 dapat menaikkan kadar $\mathrm{N}$ total tanah sebanyak $23,5 \%$ dan aplikasi pupuk hayati $10 \mathrm{~L} \mathrm{ha}^{-1}$ menaikkan $\mathrm{N}$ total tanah sebanyak 15,2\% dibandingkan dengan tanpa pemberian $A$. pinnata dan pupuk hayati. Hal ini menunjukkan bahwa pemberian A. pinnata dan pupuk hayati memberikan kontribusi mening- katkan $\mathrm{N}$ total tanah meskipun peningkatannya tidak berbeda nyata.

Kadar N organik merupakan bagian terbesar dari $\mathrm{N}$ yang terdapat di dalam tanah. Bentuk N organik di dalam tanah dapat berupa bahan organik tanah atau hasil penambatan $\mathrm{N}_{2}$ mikrob tanah dan hanya sebagian kecil (2-5\%) berbentuk $\mathrm{N}$ anorganik yaitu $\mathrm{NO}_{3}{ }^{-}$dan $\mathrm{NH}_{4}{ }^{+}$ juga $\mathrm{NO}_{2}$ dalam jumlah sedikit. Pada tanah tergenang $\mathrm{N}$ menjadi hara yang non stabil karena terjadi proses mineralisasi bahan organik (amonifikasi, nitrifikasi dan denitrifikasi) oleh mikroba di dalam tanah (Prasetyo dkk., 2004).

Nisbah $\mathrm{C} / \mathrm{N}$ tanah pada perlakuan yang ditambah A pinnata maupun pupuk hayati tidak berbeda dibandingkan perlakuan tanpa penambahan Azolla dan pupuk hayati. Nisbah $\mathrm{C} / \mathrm{N}$ tanah yang diberi perlakuan cenderung mengalami penurunan hal ini disebabkan adanya penambahan azolla maupun bakteri Azotobacter dari pupuk hayati menambah asupan $\mathrm{N}$ di dalam tanah sehingga dapat menurunkan $\mathrm{C} / \mathrm{N}$ rasio di dalam tanah. Walaupun penurunan $\mathrm{C} / \mathrm{N}$ tidak berbeda nyata dibandingkan dengan kontrol. Peningkatan kandungan nitrogen yang signifikan sebagai hasil dari kandungan $\mathrm{N}$ yang tinggi di azolla dilaporkan oleh Bhuvaneshwari (2012). Di tanah sawah, mineralisasi nitrogen organik menjadi amonia adalah proses yang penting (Dawar dan Singh, 2002). Tingkat mineralisasi 
bahan organik di dalam tanah dipengaruhi diantaranya oleh $\mathrm{C} / \mathrm{N}$. Tanaman dengan $\mathrm{C} / \mathrm{N}$ yang rendah termineralisasi dalam 2 hari sedangkan tanaman dengan $\mathrm{C} / \mathrm{N}$ tinggi termineralisasi lebih dari 5 hari (Wang dan Nii, 2000). Tingkat mineralisasi N-organik Azolla pinnata tergantung pada kondisi lingkungan seperti keasaman tanah, suhu, rasio $\mathrm{C} / \mathrm{N}$, kandungan air, dan kandungan liat tanah (Nemati et. al., 2011). Proses mineralisasi juga dipengaruhi oleh frekuensi menerapkan bahan organik atau menambahkan pupuk hijau.

\section{KESIMPULAN}

Berdasarkan hasil percobaan yang telah dilaksanakan, ditarik kesimpulan; interaksi terjadi antara $A$. pinnata dengan pupuk hayati terhadap peningkatan total populasi bakteri. Total jamur, mikrofauna (nematoda), dan $\mathrm{N}$ total tanah tidak meningkat dengan penambahan azolla maupun pupuk hayati. Secara mandiri A. pinnata dapat meningkatkan $\mathrm{C}$ organik tanah dan pupuk hayati dapat meningkatkan total populasi aktinomiset.

\section{Ucapan Terimaksih}

Penulis mengucapkan terimakasih kepada mahasiswa Dena Heldira Surya Diyati atas bantuan selama penelitian berlangsung.

\section{DAFTAR PUSTAKA}

Adhikary, B. H. 2014. Green-Manuring for Increased Crop Production. Nepal Agriculture Research Council (NARC). Khumatar. Lalitpur.

Adrian, R and Schneider-Olt, B. 1999. Topdown effects of crustacean zooplankton on pelagic microorganisms in a mesotrophic lake. J. Plankton Res. 21(11): 2175-2190.

Awais, M., M. Tariq, A. Ali, Q. Ali, A. Khan, B. Tabassum, I.A. Nasir, T. Husnain. 2017. Isolation, characterization and interrelationship of phosphate solubilizing bacteria from the rhizosphere of sugarcane and rice. Biocatalysis and Agricultural Biotechnology. 11:312321.
Tim Sintesis Kebijakan. 2008. Pemanfaatan biota tanah untuk keberlanjutan produktivitas pertanian lahan kering masam. Pengembangan Inovasi Pertanian 1(2): 157-163.

Bhuvaneshwari, K. 2012. Beneficial effects of blue-green algae and azolla in rice culture. Environment Conservation 13(1 \& 2):1-5.

Coleman D.C, M. A. Callaham, and D. A. Crossley. 2018. Fundamentals of Soil Ecology. Academic Press. USA.

Dawar, S. and Singh, P. K. 2002. Comparison of soil and nutrient based medium for maintenance of Azolla cultures. J. Plant. Nutr. 25(12): 2719-2729.

Hardjowigeno, S. 2007. Ilmu Tanah. Akademika Pressindo, Jakarta.

Kanti, A. 2005. Aktinomiset Selulolitik dari Tanah Hutan Tanaman Nasional Bukit Duabelas, Jambi. Biodiversitas 6(2): 85-89.

Karama, A. S., A.R. Marzuki, dan I. Manwan. 1990. Penggunaan pupuk organik pada tanaman pangan. Dalam Prosiding Lokakarya Nasional Efisiensi Pupuk V. Lanham The Entomological Society of American 1991. Cisarua 12-13 Nopember 1990.

Kuwabara, R. 1999. Dynamic of water quality and planktonic community in a paddy of northeastern Hokkaido along with the growth of rice plant. Dalam Proceedings of International Seminar on Development of Agribusiness and its Impact on Agricultural Production in Southeast Asia. Tokyo, 14-19 November 1998. p. 434-442.

Lavelle, P and Spain, A. V. 2001. Soil Ecology. Kluwer Academic Publisher. Dordrecht.

Maftuchah, 1994. Asosiasi Azolla Dengan Anabaena Sebagai Sumber Nitrogen Alami dan Manfaatnya Sebagai Bahan Baku Protein. Pusat Bioteknologi Pertanian. Universitas Muhammadiyah Malang.

Mirsam H. dan Kurniawati, F. 2018. Laporan pertama di Sulawesi Selatan: karakter morfologi dan molekuler nematoda puru akar yang berasosiasi dengan akar padi di Kabupaten Wajo, Sulawesi 
Selatan. Jurnal Perlindungan Tanaman Indonesia. 22 (1): 58-65.

Nemati, I., F. Moradi, S. Gholizadeh, M.A. Esmaeili, and M.R. Bihamta. 2011. The effect of salinity stress on ions and soluble sugars distribution in leaves. leaf aheaths and roots of rice (Oryza sativa L.) seedlings. Plant Soil Environment. 57(1): 26-33.

Pramono, J., S. Kartaatmadja, H. Supadmo, S. Basuki, S. C. B. Setianingrum, Yulianto, H. Anwar, S. Jauhari, Hartoko, E. B. Prayitno, P. Hasapto, dan Sartono. 2001. Pengkajian pengelolaan tanaman terpadu pada Padi Sawah. Balai Pengkajian Teknologi Pertanian Jawa Tengah. Ungaran. [Laporan Pengkajian].

Prasetyo, B. H., J. S. Adiningsih, K. Subagyono dan R.D.M. Simanungkalit. 2004. Mineralogi, kimia, fisika, dan biologi tanah sawah. Dalam: Agus, F. (Ed.) Tanah Sawah dan Teknologi Pengelolaannya. Pusat Penelitian dan Pengembangan Tanah dan Agroklimat. Bogor. Hal: 29-81.

Priadi, D, T. Kuswara dan U. Soetisno. 2007. Padi organik versus non organik: studi fisiologi benih padi kultivar lokal rojolele. J. llmu Ilmu Pertanian. 9(2): 130-138.

Rifai, M. R., H. Widowati, dan A. Sutanto. 2020. Sinergisme dan antagonisme beberapa jenis isolat bakteri yang dikonsorsiumkan. BIOLOVA. 1(1): 19 - 24.

Roper, M. M. and Ophel-Keller, K.M. 1997. Soil microflora as bioindicators of soil health. Dalam Pankhrust, C et. al. (Eds.) Biological Indicators of Soil Health. CABI Publishing. New York. p: 157-178.

Saraswati, R. 2008. Prospek penggunaan pupuk hayati pada tanah sawah. Dalam Agus, F. (Ed.) Lahan Sawah Bukaan Baru. Pusat Penelitian dan Pengembangan Tanah dan Agroklimat. Bogor. Hal: 151 - 173.

Saraswati, R., T. Prihatini, dan R. D. Hastuti. 2004. Teknologi pupuk mikroba untuk meningkatkan efisiensi pemupukan dan keberlanjutan sistem produksi padi sawah. Dalam: Agus, F et. al. (Eds.). Tanah Sawah dan Teknologi Pengelolaannya. Pusat Penelitian dan
Pengembangan Tanah dan Agroklimat. Bogor. Hal: 169-189.

Setyorini, D. 2005. Pupuk organik tingkatkan produksi tanaman. Warta Penelitian dan Pengembangan Pertanian. 27: 1315.

Dinapriatna, N dan Simarmata, T. 2011. Viabilitas pupuk hayati penambat nitrogen (Azotobacter dan Azospirillum) ekosistem padi sawah pada berbagai formulasi bahan pembawa. CEFARS: Jurnal Agribisnis dan Pengembangan Wilayah. 3(1) : 1-8.

Simpson, I. C., P. A. Roger, R. Oficial, and I. F. Grant. 1994. Effects of nitrogen fertilizer and pesticide management of floodwater ecology in a wetland ricefield II. dynamics of microcrustaceans and dipteran larvae. Biol. Fertil. Soils. 17:138-146.

Singh, P. K. and Subudhi, B. P. R. 1978. Utilization of Azolla in poultry feed. Indian Farming. 27: 37-39.

Sivasakthi S., P. Saranraj, and P. Sivasakthivelan. 2017. Biological nitrogen fixation by Azotobacter sp. - a review. Indo-Asian Journal of Multidisciplinary Research. 3(5):12741284.

Srikandi, F. 1989. Petunjuk Laboratorium Analisis Mikrobiologi Pangan. Pusat Antar Universitas Pangan dan Gizi, IPB. Bogor.

Srikandi. 2010. Hubungan Antara Tingkat Residu Pestisida dan Komunitas Biota Tanah Pada Lahan Padi Sawah. Institut Pertanian Bogor. [Thesis]

Sutanto, R. 2002. Pertanian Organik Menuju Pertanian Alternatif dan Berkelanjutan. Kanisius. Yogyakarta.

Wang, Y. and Nii, N. 2000. Changes in chlorophyll. ribulose bisphosphate carboxylase-oxygenase glycine betaine content. photosynthesis and transpiration in Amaranthus tricolor leaves during salt stress. J. Hortic. Sci. Biotech. 75(6): 623-627.

Yoshida, T. 1978. Microbial metabolism in rice soils. In International Rice Research Institute (Ed.). Soils and Rice. The International Rice Research Institute, Manila. pp. 445-463. 